\title{
EFFECT OF MUSIC THERAPY ON ANXIETY FOR PATIENTS UNDERGOING CARDIAC SURGERY: A SYSTEMATIC REVIEW
}

\author{
Sidik Awaludin'), Elly Nurachmah²), Dwi Novitasari3) \\ ${ }^{1)}$ School of Nursing, Universitas Jenderal Soedirman, Indonesia \\ 2) Faculty of Nursing, Indonesia Universitas, Indonesia \\ 3)Faculty of Health Sciences, Universitas Harapan Bangsa, Indonesia
}

\begin{abstract}
Background: Cardiac surgery is a common interventional procedure for ischemic and valvular heart disease. Cardiac surgery is accompanied by postoperative pain and anxiety. The use of music therapy has been shown to reduce pain, anxiety, and physiological parameters in patients having surgical procedures. This study aimed to review systematically the effect of music therapy on anxiety for patients undergoing cardiac surgery.

Subjects and Method: A systematic review was conducted by searching the following databases included Pro-quest, EBSCO, Science Direct, Springer Link, NCBI, and Research Gate which published articles from 2013 to 2018. The keywords for this review included music therapy, undergoing, and cardiovascular surgery. The inclusion criteria were review, systematic review, clinical review and guidelines. After review process five articles were included in this review.

Results: Music therapy significantly reduced anxiety levels in pre-operative, intra-operative, and post-operative. However the effectiveness of music therapy in perioperative cardiovascular surgery remains inconclusive.

Conclusion: The effect of music therapy on anxiety for patients undergoing cardiac surgery is remains inconclusive. Additional researches are needed to provide a strong evidence.
\end{abstract}

Keywords: anxiety, cardiovascular surgery, music therapy

\section{Correspondence:}

Sidik Awaludin. School of Nursing, Jenderal Soedirman University, Indonesia.

Email: abifayza@yahoo.co.id. Mobile: 0819-0140-5785

The 5th International Conference on Public Health

Best Western Premier Hotel, Solo, Indonesia, February 13-14, 2019 | 630

https://doi.org/10.26911/theicph.2019.05.22 